\title{
Determination of Risk Areas in the Cimahi City (Drainage Sector) Based on City Sanitation Strategy Guidelines
}

\author{
Iwan Juwana*, Elvira Rizqita Utami \\ Department of Environmental Engineering, Institut Teknologi Nasional (ITENAS) Bandung, INDONESIA \\ jL. PHH Mustafa 23 Bandung 40123, West Java \\ *Corresponding authors: juwana@itenas.ac.id
}

SUBMITTED 31 December 2019 REVISED 21 February 2020 ACCEPTED 30 April 2020

\begin{abstract}
Cimahi is one of the cities which participated in the Accelerated Habitat Sanitation Development Program in 2011 due to its poor sanitation conditions. The city experienced high flooding in 2018 as observed in the 36.4 hectares or approximately $0.76 \%$ of the total area affected even though its drainage system was discovered to be covering $89.87 \%$ in 2015 . There are also several reports of displacement of residents and significant financial loss in the city due to flooding in the past decade and this means urgent attention needs to be provided to improve the condition of the city. Therefore, this study was conducted to calculate the level of risk from the drainage sector in each urban village of Cimahi City. This involves using scores ranging from $1-4$, with a score of 1 indicating very low risk while 4 represents very high risk based on exposure factors such as percentage of inundation area, sanitation risk index (IRS) score, and the opinions of local government as well as impact factors such as population, population density, poverty rate, and urban/rural function. The research made use of both primary and secondary data with the primary data obtained through interviews with the population in the study area and local government representatives while secondary data were obtained from different institutions. The results showed 7 out of the 16 urban villages in Cimahi City are in Risk Category 1, 5 in Category 2, 1 in Category 3, and the remaining 2 in Category 4. This information with the risk category map for each village is expected to be used by the local government of Cimahi to analyze the flood-related problems better and create more effective solutions.
\end{abstract}

KEYWORDS Drainage; Risk Score; Exposure Factors; Impact Factors; Risk Areas.

(c) The Author(s) 2020. This article is distributed under a Creative Commons Attribution-ShareAlike 4.0 International license.

\section{INTRODUCTION}

The recent growth, development, and increase in population density in many areas of Indonesia including Cimahi City have increased the pressure on space and the environment and this is evident in the need for housing, industrial/service areas, and supporting facilities which have led to the transformation of open land and/or wetlands into built-up areas (Iwan Juwana, Muttil, \& Perera, 2014, I. Juwana, B. Perera, \& N. Muttil, 2009, Noor \& Pratiwi, 2016, Nursidika, Sugihartina, Susanto, \& Agustina, 2018, Sutiarani \& Rahmafitria, 2016). This further has severe impacts on the capacity of urban drainage and flood control facilities and infrastructures such as rivers, reservoirs, flood pumps, and regulating gates to drain water to its final destination, which is usually the sea (Imrona, Budiutama, Darwiyanto, \& Handayani, 2019, Wijaya \& Permana, 2017).

Cimahi is one of the cities that participated in the 2011 Sanitation Settlement Development Acceleration Program (Samyahardja, 2019; Triningtyas \& Putri, 2019) based on the poor sanitation conditions as observed by the Cimahi City Government (Bahari, Kastolani, Waluya, \& Geografi, 2016; Herdianti, Gemala, \& Erfina, 2019) which are particularly drainage-related as evident with the occurrence of flood in several areas of the city. According to the drainage master plan released by the Local Planning 
Agency (OPD), there are 36 floods spots and 2 floods areas in the Cimahi Tengah sub-district alone which are mainly caused by the poor condition of drainage infrastructure and public sanitation attitudes. These have, however, led to infrastructural damage, economic loss, and a decrease in community health in the last decade (Fauziah, Putu, Sukmono, \& Karnisah, 2018; Nandi, 2018; Wisata, Wardhani, \& Sulistyowati, 2019).

This, therefore, shows the need to develop an appropriate sanitation strategy for Cimahi City and this led to the conduct of the study to determine the risk areas related to the management of drainage system in order to have the adequate information in formulating the strategy (Fionita \& Juwana, 2019; Yasya \& Juwana, 2019).

\section{METHODS}

This study was conducted using both primary and secondary data. The primary data were mainly on the sanitation risk index of the community and opinion of local governments which were obtained through questionnaires while secondary data including the maps of the area, existing flood spots, population, population density, and poverty rate were retrieved from the documents provided by government institutions.

The research was conducted using the following steps:

1. Determination of Weights for Exposure and Impact

The importance of exposure and impact factors is not equal, and this means there is a need to assign certain weights for each of them and their subsequent parameters. The exposure factor has 3 parameters which are the percentage of inundation area, IRS score, and OPD perception while impact factor has 4 which are the population, population density, poverty rate, and urban/rural function. An Analytical Hierarchy Process (AHP) was, however, used due to its consideration as the most suitable method in this context (Diana \& Utari, 2019).

A pairwise comparison was conducted for each parameter of both exposure and impact factors to determine the weight. The rating for the exposure factor is as follows:

- Total population takes precedence over population density.

- Total population takes precedence over poverty rate.

- The population is preferred over the urban/rural function.

- Population density takes precedence over poverty rates.

- Population density takes precedence over urban/rural functions.

- The poverty rate takes precedence over urban/rural function.

The rating for the impact factors are as follows:

- Percentage of pool area takes precedence over IRS.

- Percentage area of inundation takes precedence over OPD perception.

- IRS takes precedence over OPD perception.

2. Determination of Exposure Score

The exposure score was calculated by aggregating the values for the inundation area, IRS score, and OPD perception after the weights have been obtained (Fionita \& Juwana, 2019; Sunik, Kristianto, \& Khamelda, 2018; Yasya \& Juwana, 2019). These values were normalized using a computer-based application provided by the National Development Planning of Indonesia (BAPPENAS) with the value for the parameters obtained as follow:

a. Percentage Area of Inundation

The value for each urban village in the studied area was calculated using the following Equation (1) (Yasya \& Juwana, 2019).

$\%$ inundation area $=\frac{\text { Inundation Area per Urban Village }}{\text { Administrative Area per Urban Village }}$

b. IRS Score Based on EHRA 
This was calculated using the following steps:

- Stratification of Urban Village

The samples were selected through stratified random sampling method based on certain population differences (de Oliveira Arieira, Santiago, Franchini, \& de Fátima Guimarães, 2016; Jing, Tian, \& Huang, 2015; Shields, Teferra, Hapij, \& Daddazio, 2015) including population density, poverty rates, areas drained by rivers, and areas affected by flooding.

- Determination of the Number of Family as Samples

A certain number of families were selected as samples through the use of the Slovin formula presented in the following Equation (2).

$n=\frac{N}{1+N \times e^{2}}$

Where $n$ is the number of samples, $N$ is the number of family in Cimahi City while $e$ is an error of $10 \%$

- Determination of Number of Respondents The number of respondents for each urban village was also obtained based on the stratified sampling method. This involved multiplying the number of family and percentage of urban villages per stratum as shown in Equation (3).

$N R 1=n \times \% R$

Where NR1 is the number of respondents in stratum $1, n$ is the number of family card samples, and $\% R$ is the percentage of urban village per stratum.

- Determination of Dangerous Sources From each question, 1 - 2 answers were selected to determine the level of danger and weight to be used in calculating the risk index.

For example, the following question was included in the questionnaire.
Q1: Is there a waste disposal facility apart from feces disposal in your house?
A :(a). Yes, there is.
(b). No, there is not.

- Weighting

The weight for each question is determined based on its level of risk to the drainage (I Juwana, Muttil, \& Perera, 2016a, 2016b; I. Juwana, Muttil, \& Perera, 2012; I Juwana, Perera, \& Muttil, 2010; I. Juwana, B. J. C. Perera, \& N. Muttil, 2009). For example, the previous sample question is weighted $20 \%$ due to its possible strong effects on the final IRS score.

- Environmental Risk Index Score (IRS) This was calculated after the information has been obtained from the respondents using Equations (4) and (5).

$\% Q 1=\frac{\text { number of respondents that selected a particular }}{\text { total of respondents }} \times$
$100 \%$
$n Q 1=$ weight $\times \% Q 1$

Where $\% Q 1$ is the percentage of respondents that selected a particular answer from question number 1 (Q1) while $n Q 1$ is the risk index score for $Q 1$ after which the final risk index score was calculated by aggregating the risk index scores for all the questions.

c. Relevant Local Institution (Organisasi Perangkat Daerah, known as OPD) Perception

This was a risk assessment conducted based on the experience or expertise of OPD members on the drainage component in Cimahi City. This study made use of 5 OPDs to provide perceptions for drainage risk scores and the values were obtained as an average of the overall perception score provided.

The values from the parameters were later converted to a score between 1-4 as shown in 
the following Equations (6) to (9) (Yasya \& Juwana, 2019).

$$
\begin{aligned}
& X>X_{\text {min }}+75 \% \cdot\left(X_{\text {max }}-X_{\text {min }}\right) \rightarrow 4 \rightarrow \\
& \text { very high risk } \\
& X>X_{\text {min }}+50 \% \cdot\left(X_{\text {max }}-X_{\text {min }}\right) \rightarrow 3 \rightarrow \\
& \text { high risk } \\
& X>X_{\text {min }}+25 \% \cdot\left(X_{\text {max }}-X_{\text {min }}\right) \rightarrow 2 \rightarrow \\
& \text { low risk } \\
& X>X_{\text {min }}+0 \% \cdot\left(X_{\text {max }}-X_{\text {min }}\right) \rightarrow 1 \rightarrow \\
& \text { very low risk }
\end{aligned}
$$

Where $x$ is value per parameter, $X_{\min }$ is the smallest value in every urban village, and $X_{\max }$ is the largest value in every urban village.

The exposure scores were calculated using Equation (10) after the values have been obtained (Yasya \& Juwana, 2019).

Exposure Score $=(E 1 \times B 1)+(E 2 \times B 2)+(E 3 \times$

Where $E 1$ is the score of percentage inundation area, $B 1$ is the weight percentage of inundation area, $E 2$ is the IRS score, $B 2$ is the IRS score weights, $E 3$ is the OPD perception score, and $B 3$ is the weight perception of OPD.

\section{Determination of Impact Score}

The 4 parameters used in determining the impact score include population, population density, poverty rate, and urban/rural function.

a. Population

The population was calculated by dividing the total population of the village with the number of residents in the city using the following Equation (11).

Population $=\frac{\text { urban village population }}{\text { city population }} \times 100 \%$

b. Population density

The population density value was calculated by dividing the total population by the built area in person/Ha as described in Equation (12).

Population density $=\frac{\text { population }}{\text { wide built area }} \times 100 \%$

c. Poverty rate

The poverty rate was calculated by dividing the number of poor households and the total number of households using Equation (13).

Poverty rate $=\frac{\text { population of poor family card }}{\text { total family card }} \times 100 \%$

d. Urban/Rural Function

The urban/rural function in each district was based on the Central Bureau of Statistics with value 1 applied for rural and 2 for urban function.

All the scores were later converted to a score of 1-4 using Equations (6) to (9) after which the impact score was calculated with Equation (14).

Impact score $=(E 4 \times B 4)+(E 5 \times B 5)+(E 6 \times B 6)+$

$$
(E 7 \times B 7)
$$

Where E4 is population score, $B 4$ is population weight, $E 5$ is population density score, $B 5$ is population density weight, E6 is poverty rate score, $B 6$ is poverty rate weight, $E 7$ is urban/rural function score, and $B 7$ is urban/rural function weight.

4. Drainage Risk Score Calculation and Mapping The drainage risk scores were calculated using the following Equation (15) after the exposure and impact scores have been determined (Yasya \& Juwana, 2019).

Drainage Risk Score $=$ Exposure Score $\mathrm{x}$ Impact

$$
\text { Score }
$$

The final drainage scores obtained for each urban village were plotted in a map to provide better visualization of the risk. The red color on the map represents a score value of 4 or the highest risk, yellow for 3 , green for 2 , and blue for 1 which is the lowest risk. 


\section{RESULTS AND DISCUSSION}

\subsection{Weighting of Exposure and Impact Scores}

The weights assigned to each parameter of exposure and impact factors are shown in Table 1 and 2.

Table 1. Exposure Parameters' Weight

\begin{tabular}{ll}
\hline Parameter & Weights \\
\hline Percentage of Inundation & $70 \%$ \\
IRS Score & $24 \%$ \\
OPD Perception & $6 \%$ \\
\hline
\end{tabular}

Source: Calculation Results, 2019

Table 2. Impact Parameters' Weight

\begin{tabular}{ll}
\hline Parameter & Weights \\
\hline Population & $44 \%$ \\
Population Density & $32 \%$ \\
Poverty Rate & $17 \%$ \\
Urban/Rural Function & $7 \%$ \\
\hline
\end{tabular}

\subsection{Exposure Score Determination}

The three parameters used in determining the exposure score were the percentage of inundation area, IRS score, and OPD perception and later converted into the range 1-4.

\section{a. Percentage of Inundation Area}

This was calculated by dividing the inundation area with the administrative area (Perdani \& Yusuf, 2016; Sitorus, Ashri, \& Panuju, 2016) and the risk scores obtained are presented in Table 3.

b. IRS Score

The different levels in each urban village were determined using four main criteria including population density, poverty rates, areas drained by rivers, and areas affected by flooding and no urban village was found to be in levels 0 and 1 while six including
Pasirkaliki, Citeureup, Cipageran, Baros, Leuwigajah, and Cibeber were in level 2, six others including Cibabat, Karangmekar, Setiamanah, Padasuka, Cimahi, and Melong in level 3, and three including Central Cigugur, Cibeureum, and Utama were in level 4.

Slovin formula with an error rate of $10 \%$ showed 100 families were to be surveyed after the level or strata for each village has been identified.

\section{c. OPD Perception}

The OPD's perception was obtained from the interviews conducted with the head and staff in the city drainage section of the Department of Housing and Settlement and the scores were calculated based on an average of 5 (five) scores provided by the head and staff with the results shown in Table 3.

The exposure scores were calculated by multiplying the scores of the parameters with their respective weights and the results are shown in Table 3.

\subsection{Determination of Impact Score}

This was also calculated using different parameters including population, population density, poverty rate, and urban/rural function, and the results are presented in Table 4.

\subsection{Drainage Risk Score Calculation and Mapping}

The drainage risk score was calculated by multiplying the exposure and impact scores and the results are presented in Table 5 and plotted in the map shown in Figure 1. 
Table 3. Exposure Score Calculation

\begin{tabular}{|c|c|c|c|c|c|c|c|c|c|}
\hline \multirow{3}{*}{$\begin{array}{l}\text { Sub } \\
\text { District }\end{array}$} & \multirow{3}{*}{$\begin{array}{l}\text { Urban } \\
\text { Village }\end{array}$} & \multicolumn{2}{|c|}{$\begin{array}{l}\text { Percentage of } \\
\text { Inundation Area }\end{array}$} & \multicolumn{2}{|c|}{ IRS Score } & \multicolumn{2}{|c|}{ OPD Perceptions } & \multirow[t]{2}{*}{ Score } & \multirow[t]{2}{*}{$\begin{array}{l}\text { Exposure } \\
\text { Score }\end{array}$} \\
\hline & & $\begin{array}{l}\text { Data } \\
(\%)\end{array}$ & $\begin{array}{l}\text { Normalization } \\
\text { Score }\end{array}$ & Data & $\begin{array}{l}\text { Normalization } \\
\text { Score }\end{array}$ & Data & $\begin{array}{l}\text { Normalization } \\
\text { Score }\end{array}$ & & \\
\hline & & $70 \%$ & & $24 \%$ & & $6 \%$ & & & \\
\hline \multirow{4}{*}{$\begin{array}{l}\text { North } \\
\text { Cimahi }\end{array}$} & Cipageran & $0.71 \%$ & 2 & 47 & 4 & 2.4 & 1 & 2.4 & 3 \\
\hline & Citeureup & $1.08 \%$ & 3 & 47 & 4 & 2 & 1 & 3.1 & 4 \\
\hline & Cibabat & $0.66 \%$ & 2 & 46 & 4 & 2.4 & 1 & 2.4 & 3 \\
\hline & Pasirkaliki & $0.09 \%$ & 1 & 47 & 4 & 2 & 1 & 1.7 & 2 \\
\hline \multirow{6}{*}{$\begin{array}{l}\text { Central } \\
\text { Cimahi }\end{array}$} & Cimahi & $0.22 \%$ & 1 & 46 & 4 & 2.4 & 1 & 1.7 & 2 \\
\hline & Karangmekar & $0.02 \%$ & 1 & 46 & 4 & 2 & 1 & 1.7 & 2 \\
\hline & Padasuka & $1.83 \%$ & 4 & 46 & 4 & 2.4 & 1 & 3.8 & 4 \\
\hline & Setiamanah & $0.97 \%$ & 3 & 46 & 4 & 2.4 & 1 & 3.1 & 4 \\
\hline & Baros & $0.25 \%$ & 1 & 47 & 4 & 2 & 1 & 1.7 & 2 \\
\hline & $\begin{array}{l}\text { Central } \\
\text { Cigugur }\end{array}$ & $1.31 \%$ & 3 & 40 & 1 & 2.4 & 1 & 2.4 & 2 \\
\hline \multirow{5}{*}{$\begin{array}{l}\text { South } \\
\text { Cimahi }\end{array}$} & Utama & $0.45 \%$ & 1 & 40 & 1 & 2.2 & 1 & 1 & 1 \\
\hline & Leuwigajah & $0.52 \%$ & 2 & 47 & 4 & 2.2 & 1 & 2.4 & 3 \\
\hline & Cibeber & $0.05 \%$ & 1 & 47 & 4 & 2.4 & 1 & 1.7 & 2 \\
\hline & Cibeureum & $0.54 \%$ & 2 & 40 & 1 & 2 & 1 & 1.7 & 1 \\
\hline & Melong & $1.00 \%$ & 3 & 46 & 4 & 3.4 & 4 & 3.3 & 4 \\
\hline \multicolumn{2}{|c|}{ Maximum Value } & & & & & & & 3.8 & - \\
\hline \multicolumn{2}{|c|}{ Minimum Value } & & & & & & & 1 & - \\
\hline \multicolumn{2}{|c|}{ Interval } & & & & & & & 2.8 & - \\
\hline
\end{tabular}

Table 4. Impact Score Calculation

\begin{tabular}{|c|c|c|c|c|c|c|c|c|c|c|}
\hline \multirow{3}{*}{$\begin{array}{l}\text { Sub } \\
\text { District }\end{array}$} & \multirow{3}{*}{$\begin{array}{l}\text { Urban } \\
\text { Village }\end{array}$} & \multicolumn{2}{|c|}{ Population } & \multicolumn{2}{|c|}{ Population Density } & \multicolumn{2}{|c|}{ Poverty Rate } & \multirow{2}{*}{$\begin{array}{l}\text { Urban/Rural } \\
\text { Function } \\
\text { Score }\end{array}$} & \multirow{3}{*}{ Score } & \multirow{3}{*}{$\begin{array}{l}\text { Impact } \\
\text { Score }\end{array}$} \\
\hline & & $\begin{array}{l}\text { Data } \\
(\%)\end{array}$ & $\begin{array}{l}\text { Normalized } \\
\text { Score }\end{array}$ & $\begin{array}{l}\text { Data } \\
\text { (Person } \\
/ \mathrm{Ha} \text { ) }\end{array}$ & $\begin{array}{l}\text { Normalized } \\
\text { Score }\end{array}$ & $\begin{array}{l}\text { Data } \\
(\%)\end{array}$ & $\begin{array}{l}\text { Normalized } \\
\text { Score }\end{array}$ & & & \\
\hline & & $44 \%$ & & $32 \%$ & & $17 \%$ & & $7 \%$ & & \\
\hline \multirow{4}{*}{$\begin{array}{l}\text { North } \\
\text { Cimahi }\end{array}$} & Cipageran & 8.63 & 3 & 145 & 1 & 4.7 & 1 & 2 & 2.0 & 2 \\
\hline & Citeureup & 6.87 & 2 & 212 & 2 & 5.1 & 1 & 2 & 1.8 & 2 \\
\hline & Cibabat & 9.77 & 4 & 340 & 4 & 5.2 & 1 & 2 & 3.4 & 4 \\
\hline & Pasirkaliki & 3.40 & 1 & 267 & 2 & 4.9 & 1 & 2 & 1.4 & 1 \\
\hline \multirow{6}{*}{$\begin{array}{l}\text { Central } \\
\text { Cimahi }\end{array}$} & Cimahi & 2.40 & 1 & 285 & 3 & 9.8 & 4 & 2 & 2.2 & 2 \\
\hline & Karangmekar & 2.97 & 1 & 226 & 2 & 7.9 & 3 & 2 & 1.7 & 1 \\
\hline & Padasuka & 7.10 & 3 & 358 & 4 & 7.9 & 3 & 2 & 3.3 & 4 \\
\hline & Setiamanah & 4.24 & 1 & 308 & 3 & 8.3 & 3 & 2 & 2.1 & 2 \\
\hline & Baros & 3.83 & 1 & 170 & 1 & 5.8 & 1 & 2 & 1.1 & 1 \\
\hline & $\begin{array}{l}\text { Central } \\
\text { Cigugur }\end{array}$ & 8.64 & 3 & 367 & 4 & 10.6 & 4 & 2 & 3.4 & 4 \\
\hline \multirow{5}{*}{$\begin{array}{l}\text { South } \\
\text { Cimahi }\end{array}$} & Utama & 6.28 & 2 & 165 & 1 & 8.1 & 3 & 2 & 1.9 & 2 \\
\hline & Leuwigajah & 8.12 & 3 & 206 & 1 & 6.9 & 2 & 2 & 2.1 & 2 \\
\hline & Cibeber & 4.97 & 2 & 149 & 1 & 6.3 & 2 & 2 & 1.7 & 1 \\
\hline & Cibeureum & $\begin{array}{l}11.0 \\
7.00\end{array}$ & 4 & 402 & 4 & 10.9 & 4 & 2 & 3.9 & 4 \\
\hline & Melong & 11.71 & 4 & 374 & 4 & 4.7 & 1 & 2 & 3.4 & 4 \\
\hline \multicolumn{2}{|c|}{ Maximum Value } & & & & & & & & 3.9 & - \\
\hline \multicolumn{2}{|c|}{ Minimum Value } & & & & & & & & 1.1 & - \\
\hline Interval & & & & & & & & & 2.8 & - \\
\hline
\end{tabular}


Table 5. Drainage Risk Score

\begin{tabular}{|c|c|c|c|c|c|c|}
\hline Sub District & Urban Village & Exposure Score & Impact Score & $\begin{array}{l}\text { Score } \\
\text { Total }\end{array}$ & $\begin{array}{l}\text { Drainage Risk } \\
\text { Score }\end{array}$ & Note \\
\hline \multirow{4}{*}{ North Cimahi } & Cipageran & 3 & 2 & 6 & 2 & Low risk \\
\hline & Citeureup & 4 & 2 & 8 & 2 & Low risk \\
\hline & Cibabat & 3 & 4 & 12 & 3 & High risk \\
\hline & Pasirkaliki & 2 & 1 & 2 & 1 & Very low risk \\
\hline \multirow{6}{*}{$\begin{array}{l}\text { Central } \\
\text { Cimahi }\end{array}$} & Cimahi & 2 & 2 & 4 & 1 & Very low risk \\
\hline & Karangmekar & 2 & 1 & 2 & 1 & Very low risk \\
\hline & Padasuka & 4 & 4 & 16 & 4 & Very high risk \\
\hline & Setiamanah & 4 & 2 & 8 & 2 & Low risk \\
\hline & Baros & 2 & 1 & 2 & 1 & Very low risk \\
\hline & $\begin{array}{l}\text { Central } \\
\text { Cigugur }\end{array}$ & 2 & 4 & 8 & 2 & Low risk \\
\hline \multirow{5}{*}{ South Cimahi } & Utama & 1 & 2 & 2 & 1 & Very low risk \\
\hline & Leuwigajah & 3 & 2 & 6 & 2 & Low risk \\
\hline & Cibeber & 2 & 1 & 2 & 1 & Very low risk \\
\hline & Cibeureum & 1 & 4 & 4 & 1 & Very low risk \\
\hline & Melong & 4 & 4 & 16 & 4 & Very high risk \\
\hline Maximum Value & & & & 16 & - & - \\
\hline Minimum Value & & & & 2 & - & - \\
\hline Interval & & & & 14 & - & - \\
\hline
\end{tabular}

Source: Calculation Result, 2019

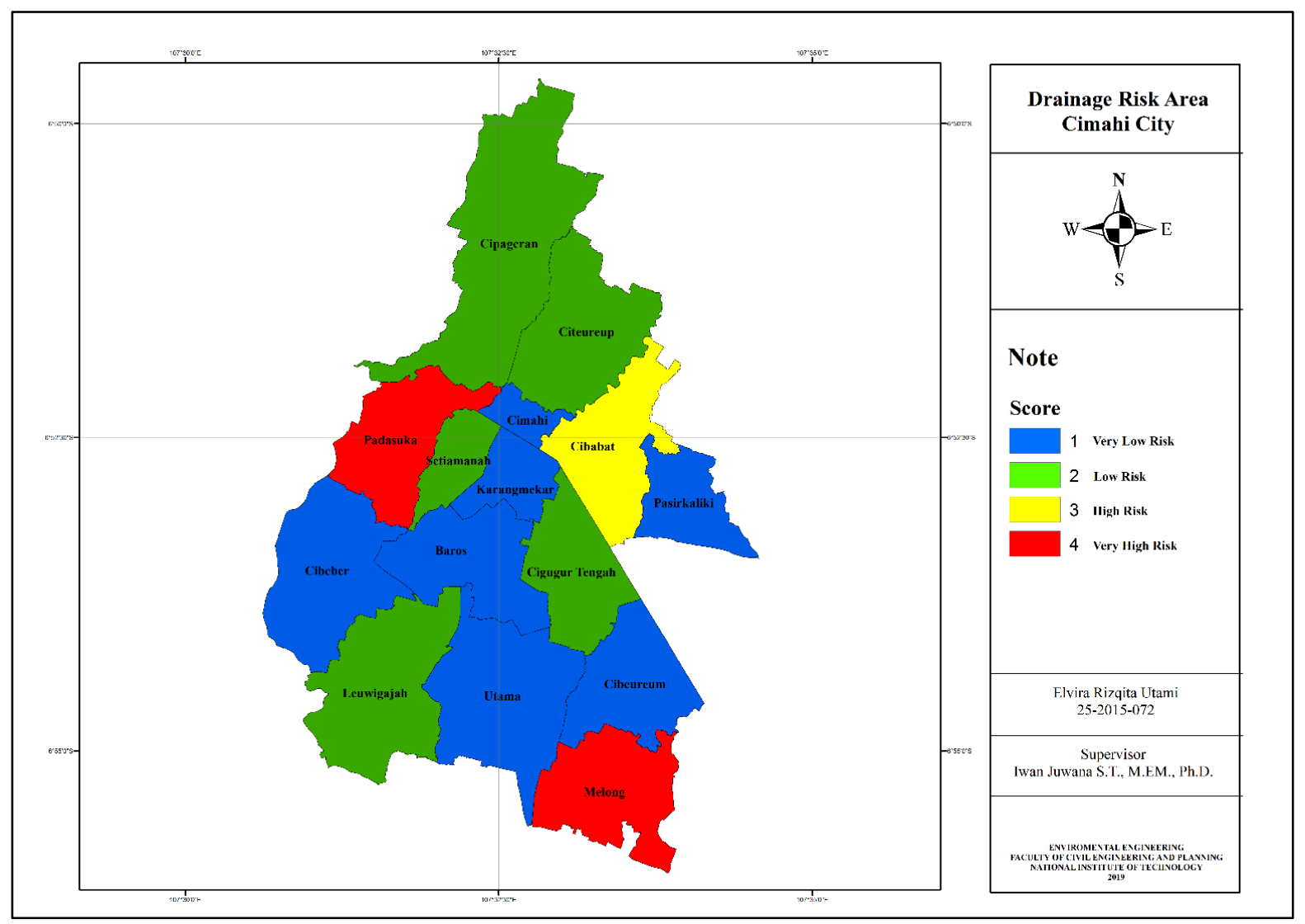

Figure 1. Mapping Drainage Risk Area in Cimahi City 
Figure 1 shows Melong and Padasuka urban villages are considered to have a very high risk of drainage issues as evident in the very low values recorded for their exposure and impact factors based on a high number of inundations areas, low number of IRS, low value from related local government officials' opinions as well as high population density and poverty rate.

The results also showed Pasirkaliki, Karangmekar, Cibeber, Baros, Cimahi, Utama, and Cibeureum have lesser inundation areas, a higher number of IRS, lower poverty rates, and significantly lower population density and these were observed to produced lower values for the overall drainage score. This, therefore, means these areas have very low drainage risk.

The drainage risk calculation also showed the exposure weight is significantly higher than the impact weight and this is observed to be due to the direct relation of the impact factors with the drainage issues while exposure factors are not significantly or directly related to these issues. This study, therefore, shows some of the urban villages have a high risk of impact factors but a low risk of exposure factors, thereby, leading to their overall lower drainage risk. This is observed in Cibeureum which was recorded to have a very low risk for exposure factors as shown by value 1 but very high risk for impact factors as indicated by 4 , thereby, leading to an overall risk of 1 or very low based on weights.

\section{CONCLUSION}

The research showed the urban villages included in very low risk with a score of 1 include Pasirkaliki, Cimahi, Karangmekar, Baros, Utama, Cibeber, and Cibeber. Those having low risk with a score of 2 were Cipageran, Citeureup, Setiamanah, Central Cigugur, and Leuwigajah. The villages classified as having high risk or score of 3 were Cibabat while those with very high risk or score of 4 were Padasuka and Melong. The results also showed the weights for impact and exposure factors have significant effects on the overall drainage risk such that the areas with higher weights of exposure factors are classified as having low drainage risk even though they have high-risk values for impact factors. It is recommended that decision-makers in Cimahi City use the risk map to develop relevant strategies to address drainage problems in the future.

\section{DISCLAIMER}

The authors declare no conflict of interest.

\section{ACKNOWLEDGMENTS}

The authors thank BAPPEDA of Cimahi City for its significant contributions to this manuscript.

\section{REFERENCES}

Bahari, R., Kastolani, W., Waluya, B., \& Geografi, D. P. 2016. Evaluasi Kualitas Lingkungan Permukiman di Kecamatan Cimahi Tengah Kota Cimahi. Universitas Pendidikan Indonesia,

de Oliveira Arieira,, G., Santiago, D. C., Franchini, J. C., \& de Fátima Guimarães, M., 2016. Depthstratified soil sampling for assessing nematode communities. Semina: Ciências Agrárias, 37(2), 715-727.

Diana, A., \& Utari, D. R., 2019. Pemodelan Sistem Penunjang Keputusan dalam Pemilihan Vendor Laptop dengan Metode Analytical Hierarchy Process (AHP) dan Simple Additive Weighting (SAW). Prosiding SeNTIK STI\&K, 3.

Fauziah, F., Putu, L. M. T., Sukmono, M., \& Karnisah, I., 2018. Perhitungan Kapasitas Drainase untuk Mengatasi Permasalahan Genangan Air di Jalan Raya Cibabat, Kampung Karang Mekar Kecamatan Cimahi Utara. Potensi: Jurnal Sipil Politeknik, 20(2), 93-97.

Fionita, I., \& Juwana, I., 2019. Pemetaan Area Berisiko Persampahan di Kota Cimahi Berdasarkan Pedoman Strategi Sanitasi Kabupaten/Kota 2018. Rekayasa Hijau: Jurnal Teknologi Ramah Lingkungan, 3(2). 
Herdianti, H., Gemala, M., \& Erfina, L., 2019. Fasilitas Sanitasi Sekolah Yang Berhubungan Dengan Keberadaan Jentik Nyamuk Aedes Aegypti Di Sekolah-Sekolah Wilayah Kerja Puskesmas Batu 10 Tanjung Pinang. Jurnal Kesmas (Kesehatan Masyarakat) Khatulistiwa, 6(1), 14-22.

Imrona, M., Budiutama, A. A., Darwiyanto, E., \& Handayani, D., 2019. Penerapan Metode AHP dan COPRAS-G untuk Menentukan Prioritas Perbaikan Drainase Pada Jalan Nasional Di Kota Bandung. Indonesian Journal on Computing (IndoJC), 4(1), 65-74.

Jing, L., Tian, K., \& Huang, J. Z., 2015. Stratified feature sampling method for ensemble clustering of high dimensional data. Pattern Recognition, 48(11), 3688-3702.

Juwana, I., Muttil, N., \& Perera, B., 2014. Application of West Java water sustainability index to Citarum catchment in West Java, Indonesia. Water Science and Technology: Water Supply, 14(6), 1150-1159.

Juwana, I., Muttil, N., \& Perera, B., 2016a. Application of west java water sustainability index to three water catchments in west java, Indonesia. Ecological indicators, 70, 401-408.

Juwana, I., Muttil, N., \& Perera, B., 2016 b. Uncertainty and sensitivity analysis of West Java Water Sustainability Index-A case study on Citarum catchment in Indonesia. Ecological indicators, 61, 170-178.

Juwana, I., Muttil, N., \& Perera, B. J. C., 2012. Indicator-based water sustainability assessmentâ€”A review. Science of The Total Environment, 438, 357-371.

Juwana, I., Perera, B., \& Muttil, N., 2009. Conceptual framework for the development of West Java water sustainability index. Paper presented at the 18th World IMACS Congress and MODSIM09 International Congress on Modelling and Simulation.
Juwana, I., Perera, B., \& Muttil, N., 2010. A water sustainability index for West Java. Part 1: developing the conceptual framework. Water science and technology: a journal of the International Association on Water Pollution Research, 62(7), 1629-1640.

Juwana, I., Perera, B. J. C., \& Muttil, N., 2009. Application of Delphi Technique for Development of a Water Sustainability Index for West Java, Indonesia. Paper presented at the 32nd Hydrology and Water Symposium, Newcastle, Australia.

Nandi, N., 2018. Flood Mitigation: Tinjauan tentang Kondisi dan Masalah Sistem Drainase serta Pengendalian Banjir di Kota Cimahi. Jurnal Geografi Gea, 10(1), pp. 87-98.

Noor, A. A., \& Pratiwi, D. R., 2016. Konsep Pengembangan Pariwisata Berkelanjutan di Kampung Buyut Cipageran (Kabuci) Kota Cimahi. Paper presented at the Prosiding Industrial Research Workshop and National Seminar.

Nursidika, P., Sugihartina, G., Susanto, E. N., \& Agustina, W., 2018. Kandungan Timbal Pada Air dan Padi di Daerah Industri Leuwigajah Cimahi. Jurnal Kesehatan Kartika, 9(1), pp. 13-22.

Perdani, F. L., \& Yusuf, H., 2016. Faktor Potensi Kekerasan Orangtua terhadap Anak: Studi Kasus di Kelurahan Cibeber, Kecamatan Cimahi Selatan Kota Cimahi Parent Violence Potential Factor to Child: Case Study in Kelurahan Cibeber South Cimahi Subdistrict-Cimahi. Jurnal Pemberdayaan Komunitas, 12(2).

Samyahardja, P., 2019. Housing Characteristic in the Densely Populated Area. A Case Study in Cigugur Tengah, Cimahi. KnE Social Sciences, 444-459-444-459.

Shields, M. D., Teferra, K., Hapij, A., \& Daddazio, R. P., 2015. Refined stratified sampling for efficient Monte Carlo based uncertainty quantification. Reliability Engineering \& System Safety, 142, 310-325. 
Sitorus, S. R. P., Ashri, M., \& Panuju, D. R., 2016. Analisis ketersediaan ruang terbuka hijau dan tingkat perkembangan wilayah di kota cimahi, provinsi jawa barat. Jurnal Ilmu Tanah dan Lingkungan, 15(2), 66-75.

Sunik, S., Kristianto, D., \& Khamelda, L., 2018. Penilaian Resiko Kesehatan Lingkungan-EHRA (Fasilitas dan Perilaku Warga Perumahan Karanglo Indah) Terhadap Sampah Rumah Tangga. Reka Buana: Jurnal Ilmiah Teknik Sipil dan Teknik Kimia, 3(2), 98-107.

Sutiarani, H., \& Rahmafitria, F., 2016. Dampak Keberadaan Dusun Bambu Terhadap Kondisi Sosial Ekonomi Masyarakat di Desa Kertawangi Kecamatan Cisarua. Tourism Scientific Journal, 1(1), 1-17.

Triningtyas, A. Y., \& Putri, T. H. K., 2019. Pola Penyebaran Tuberkulosis Paru di Kelurahan
Utama Kecamatan Cimahi Selatan Tahun 2018. Medika Kartika: Jurnal Kedokteran dan Kesehatans, 2(2), 98-109.

Wijaya, K., \& Permana, A. Y., 2017. Kawasan Cigondewah Terkait Sarana Prasarana Lingkungan Terbangun Sebagai Kawasan Wisata Tekstil Di Kota Bandung. Langkau Betang: Jurnal Arsitektur, 4(2), 79-88.

Wisata, H., Wardhani, E., \& Sulistyowati, L. A., 2019. Analisis Penentuan Lokasi Prioritas Penanganan Genangan Banjir di Kecamatan Cimahi Tengah. Paper presented at the PROSIDING SEMINAR NASIONAL CENDEKIAWAN.

Yasya, H. R., \& Juwana, I., 2019. Pemetaan Area Risiko Sanitasi Sektor Air Limbah Domestik Kota Cimahi. Jurnal Serambi Engineering, 4(2). 